\title{
Kajian Sistem Integrasi Sapi Sawit di Kabupaten Pandeglang, Provinsi Banten
}

\section{(Assesment of Oil Palm-Cattle Integration System in Pandeglang District, Banten Province)}

\author{
Malik RJ ${ }^{1}$, Kardiyanto E ${ }^{1}$, Sani $\mathrm{Y}^{2}$, Martindah $\mathrm{E}^{2}$, Yusron $\mathrm{M}^{1}$ \\ ${ }^{1}$ Balai Pengkajian Teknologi Pertanian Banten, Jl. Ciptayasa Km. 01, Serang, Banten \\ ${ }^{2}$ Balai Besar Penelitian Veteriner, Jl. RE Martadinata No. 30, Bogor 16114 \\ rikabptpbanten@yahoo.com
}

\begin{abstract}
Pandeglang is one of the designated palm cow integration development area. The assessment of oil palm-cattle integration system has been conducted in Cikeusik sub district. Pandeglang district on September 2015-Maret 2016. The objective of the assessment is to determine the characteristics of farmers and socialize of palm cow integration system. The data were collected by using a survey method with interview techniques and analyzed descriptively. Socialization and introduction of technology is the first step in the development of oil palm cow integration system. The technologies that disseminated are technology based on palm oil by product and management of waste and manure processing through the training to produce organic fertilizer. The results of monitoring and evaluation of activities that manure treatment technology being adoptif by farmer, while feed technology has not been applied yet. The observation on the farmers characteristics and the potential of existing land indicated that integration palm cow system likely developed in this location.
\end{abstract}

Key Words: Cow, Integration, Palm, Sosialization

\begin{abstract}
ABSTRAK
Kabupaten Pandeglang termasuk salah satu wilayah yang ditetapkan sebagai lokasi pengembangan integrasi sapi sawit. Kegiatan pendampingan dan kajian sistem integrasi sapi-sawit telah dilakukan di Kecamatan Cikeusik Kabupaten Pandeglang pada September 2015-Maret 2016. Tujuan kajian yaitu untuk mengetahui karakteristik peternak dan mensosialisasikan sistem integrasi sapi sawit. Pengumpulan data menggunakan metode survei dengan teknik wawancara. Data yang diperoleh dianalisis secara deskriptif. Sosialisasi dan introduksi teknologi merupakan langkah awal dalam pengembangan integrasi sapi sawit. Teknologi yang didiseminasikan yaitu teknologi pakan berbasis limbah sawit dan pengolahan limbah melalui pelatihan pembuatan pupuk organik. Hasil pengamatan terhadap karakteristik peternak serta potensi lahan yang ada, mengindikasikan bahwa sistem integrasi sapi sawit berpeluang dikembangkan di lokasi ini. Hasil monitoring dan evaluasi kegiatan diketahui bahwa teknologi pegolahan limbah mulai diadopsi oleh peternak, sedangkan teknologi pakan belum diterapkan. Hasil observasi mengenai karakteristik petani dan potensi lahan menunjukkan bahwa sistem integrasi sapi-sawit dapat dikembangkan di lokasi ini.
\end{abstract}

Kata Kunci: Sapi, Integrasi, Sawit, Sosialisasi

\section{PENDAHULUAN}

Ketersediaan produk peternakan dalam negeri belum mampu memenuhi permintaan daging yang terus meningkat. Pakan menjadi faktor utama dan memerlukan biaya besar dalam budidaya sapi. Di sisi lain, Indonesia memiliki sumber daya alam yang menghasilkan kelapa sawit. Gulma dan limbah kelapa sawit belum maksimal dimanfaatkan sebagai sumber bahan pakan ternak. Sinergis keduanya (sapi dan sawit) perlu terus 
dikembangkan melalui integrasi pemeliharaan sapi di kawasan perkebunan kelapa sawit (Manurung 2005).

Sawit menjadi komoditas primadona yang mengangkat Indonesia menjadi produsen utama minyak mentah-crude palm oil (CPO) di dunia. Perkebunan sawit berdasarkan informasi dari Direktorat Tanaman Tahunan, Direktorat Jenderal Perkebunan (2014) seluas 10.956.231 ha. Pengelolaan perkebunan sawit terbagi atas perkebunan rakyat 4.551.854 ha (41,5\%), Negara/PTPN 748.272 ha $(6,8 \%)$ dan swasta 5.656.105 ha (51,7\%). Lahan perkebunan kelapa sawit berdasarkan laporan Dinas Kehutanan Dan Perkebunan Provinsi Banten (2014) seluas 37.801 ha, terdiri atas milik masyarakat 7.745 ha $(20,49 \%)$; milik Negara 9.795 ha $(25,91 \%)$; dan swasta 20.261 ha $(53,6 \%)$ dengan rata-rata produksi tandan buah segar sebanyak $61.853 \mathrm{~kg} / \mathrm{tahun}$ yang diperoleh dari lahan milik rakyat 10.133 kg/tahun; milik negara $17.254 \mathrm{~kg} / \mathrm{tahun}$; dan milik swasta $34.466 \mathrm{~kg} / \mathrm{tahun}$. Hasil tersebut mayoritas ditampung oleh pabrik Kertajaya PT Perkebunan Nusantara VIII yang memproduksi minyak mentah (CPO) di Kabupaten Lebak.

Salah satu faktor penunjang untuk meningkatkan produktivitas tanaman kelapa sawit yaitu pemanfaatan dan penggunaan pupuk organik pada lahan kelapa sawit untuk menambah unsur hara dan memperbaiki kondisi tanah. Penyediaan pupuk organik yang murah dapat dilakukan dengan cara memelihara sapi di lahan perkebunan sawit dimana limbah kotoran sapi dimanfaatkan sebagai sumber pupuk organik. Selanjutnya untuk memenuhi kebutuhan akan pakan sapi, rerumputan dan gulma di kebun sawit serta limbah kelapa sawit seperti pelepah dan daun sawit dapat dimanfatkan untuk sapi. Pola simbiosis mutualisme sawit sapi ini sering disebut sistem integrasi sapi-kelapa sawit (SISKA) (Setiadi et al. 2011).

Sapi potong merupakan ruminansia besar yang berperan penting dalam menyumbang ketersediaan daging nasional. Populasi sapi potong pada tahun 2013 sebanyak 14.726.875 ekor dan tersebar di seluruh wilayah Indonesia (BPS 2014). Populasi sapi potong di Provinsi Banten berdasarkan data BPS Provinsi Banten (2014) sebanyak 54.989 ekor dan sebaran tertinggi di Kabupaten Tangerang 40.534 ekor (73,71\%). Laporan Dinas Pertanian dan Peternakan Kabupaten Tangerang (2015) menyebutkan bahwa jumlah sapi potong didominasi oleh keberadaan feedlotter sebanyak 31.907 ekor, sedangkan skala rumah tangga 7.067 ekor dan pedagang 1.560 ekor. Kabupaten Tangerang tidak memiliki lahan perkebunan kelapa sawit, lahan yang tercatat mayoritas milik pengembang. Dengan demikian pengembangan usaha sapi sawit seyogianya di kabupaten yang telah tersedia perkebunan sawit baik milik rakyat, negara maupun swasta.

Upaya pemerintah untuk swasembada daging telah dilaksanakan sejak tahun 2010 melalui program swasembada daging sapi/kerbau. Bangsa sapi yang tersebar di Indonesia yaitu sapi Bali, sapi Madura, sapi Peranakan Ongole (PO), Limousin, Simmental, Brahman Cross dan Angus. Peningkatan produktivitas sapi di tingkat rakyat lebih ditekankan pada penerapan teknologi budidaya sapi yang baik dan benar. Dampak penerapan teknologi budidaya sapi yaitu keuntungan yang diperoleh dari daging, susu hingga kotoran sebagai bahan dasar pupuk organik (Prabowo et al. 2008).

Konsep integrasi ternak dengan perkebunan kelapa sawit lebih berorientasi untuk menghadapi era globalisasi/perdagangan bebas. Konsep yang diterapkan menggunakan pendekatan LEISA (low eksternal input system agriculture) yaitu ketergantungan dan keuntungan yang diperoleh antara tanaman perkebunan dan ternak. Prinsipnya hasil samping limbah perkebunan dapat dimanfaatkan sebagai bahan pakan ternak, sedangkan kotoran dan sisa pakan ternak menjadi penyedia unsur hara untuk meningkatkan kesuburan tanah perkebunan (Wijono et al. 2003).

Arahan Kementerian Pertanian adalah upaya pengembangan usaha sapi sawit supaya lebih memprioritaskan pada lahan milik rakyat. Lokasi perkebunan sawit milik rakyat di 
Banten berada di Kabupaten Lebak dan Pandeglang. Balai Pengkajian Teknologi Pertanian Banten bersama Balai Besar Penelitian Veteriner berupaya mendukung pengembangan sistem integrasi sapi sawit di Kabupaten Pandeglang. Berdasarkan Permentan No: 50/Permentan/OT.140/8/2012 dan diperjelas melalui Keputusan Menteri Pertanian Republik Indonesia No: 43/Kpts/PD. 410/1/2015, Kabupaten Pandeglang merupakan wilayah pengembangan ternak kerbau. Telah terbit peta potensi dan sebaran areal perkebunan kelapa sawit di Provinsi Banten (Setiadi et al. 2011). Sehingga perlu adanya kajian untuk mengetahui karakteristik peternak sekaligus sosialisasi dan introduksi teknologi pada kelompok sasaran kegiatan sistem integrasi sapi sawit di Kabupaten Pandeglang.

\section{MATERI DAN METODE}

Lokasi kajian di Kecamatan Cikeusik Kabupaten Pandeglang, Banten pada bulan September 2015 sampai dengan Maret 2016.

Adapun jenis kegiatan yang dilakukan antara lain mengumpulkan informasi mengenai:

1. Karakteristik peternak

Data dikumpulkan melalui teknik wawancara dengan kuisioner terstruktur yang melibatkan responden kegiatan integrasi sapi sawit sebanyak 28 orang yang terdiri dari 17 orang kelompok Tanjungan-3 dan 11 orang kelompok Neglasari.

2. Potensi sumber daya alam dan sumber daya manusia

Pengumpulan data dilakukan dengan metode survei dan wawancara.

3. Sosialisasi SISKA

Pelaksanaan kegiatan dilakukan dengan cara pertemuan dan pelatihan teknis pengolahan limbah kotoran sapi menjadi pupuk organik.

4. Monitoring dan evaluasi pertumbuhan sapi

Pelaksanaan kegiatan monev dilakukan melalui pengamatan pelaksanaan kegiatan hasil sosialisasi dan pengukuran pertumbuhan sapi.

Data diperoleh dengan menggunakan pendekatan individu dengan teknik wawancara. Hasil wawancara memudahkan peneliti mengetahui hal-hal yang lebih mendalam tentang partisipan dalam menginterprestasikan situasi dan fenomena yang terjadi (Satori \& Komariah 2009). Instrumen pengambilan data yang digunakan memuat pertanyaanpertanyaan tertulis. Secara langsung anggota kelompok memberikan informasi tentang umur, pendidikan, jumlah tanggungan keluarga, pekerjaan utama, rata-rata pendapatan, pengalaman usaha sawit, penguasaan lahan sawit, penguasaan lahan tanaman pangan, pengalaman beternak sapi dan kepemilikan ternak. Selanjutnya data tersebut di-entry ke dalam program Excel dan dianalisis secara deskriptif.

\section{HASIL DAN PEMBAHASAN}

\section{Karakteristik peternak}

Anggota kelompok yang terlibat dalam kegiatan sistem integrasi sapi sawit mayoritas memiliki akses ke perkebunan sawit, baik sebagai pemilik maupun buruh. Karakteristik peternak anggota kelompok Neglasari dan Tanjungan-3 (Tabel 1) berpotensi dalam pengembangan usaha pemeliharaan sapi maupun usaha sawit. Mereka memiliki pengalaman beternak dan berkebun kelapa sawit dengan luas memadai untuk mengembangkan usaha sapi potong dan terintegrasi dengan kebun kelapa sawit. Afriani et al. (2014) juga menyatakan bahwa luas lahan kebun kelapa sawit yang dimiliki, 
pengalaman beternak, skala usaha ternak, pendapatan, jumlah tanggungan keluarga dan aktivitas kelompok mempengaruhi minat dan motivasi peternak untuk mengembangkan sapi pada perkebunan sawit di Provinsi Jambi.

Tabel 1. Karakteristik peternak yang terlibat dalam kegiatan integrasi sapi sawit di Kabupaten Pandeglang

\begin{tabular}{lcc}
\hline \hline \multirow{2}{*}{ Karakteristik } & \multicolumn{2}{c}{ Kelompok } \\
\cline { 2 - 3 } & Neglasari & Tanjungan-3 \\
\hline Umur (tahun) & $25-60$ & $23-48$ \\
Pendidikan (tahun) & $0-12$ & $0-16$ \\
Jumlah tanggungan keluarga (orang) & $3-6$ & $3-5$ \\
Pekerjaan utama & Petani & Petani \\
Rata-rata Pendapatan dari seluruh kegiatan & $500.000-5.000 .000$ & $500.000-5.000 .000$ \\
yang diusahakan (Rp/bulan) & & \\
Pengalaman usaha sawit (tahun) & 13 & 16,3 \\
Luas lahan sawit (m ${ }^{2}$ ) & 59.067 & $0,1-0,5$ \\
Luas lahan sawah (ha) & $0,4-2$ & 4,8 \\
Pengalaman beternak sapi (tahun) & 5 & $1-6$ \\
Kepemilikan ternak (ekor) & $1-7$ & \\
\hline
\end{tabular}

Umur peternak sapi (Tabel 1), anggota kelompok Neglasari memiliki kisaran umur 25-60 tahun, sedangkan anggota kelompok Tanjungan-3 relatif lebih muda yaitu kisaran 23-48 tahun. Usia ketua anggota kelompok termasuk kategori produktif. Sesuai dengan Undang-Undang Nomor 13 tahun 2003 bahwa penduduk tergolong sebagai tenaga kerja jika telah memasuki usia kerja dengan kisaran usia kerja di Indonesia adalah umur 15-64 tahun. Umur tenaga kerja berhubungan erat dengan curah waktu yang digunakan dalam pemeliharaan sapi dan usaha sawit. Hal ini telah dibuktikan oleh Ahmad (2014) bahwa umur peternak berpengaruh secara nyata $(\mathrm{P}<0,05)$ terhadap curahan waktu kerja dalam pemeliharaan sapi potong di Kabupaten Pangkep.

Pendidikan tertinggi anggota kelompok Neglasari yaitu SLTA/sederajat, sedangkan anggota kelompok Tanjungan-3 lebih tinggi yakni S1. Akan tetapi kedua anggota kelompok masih ada yang tidak lulus SD/sederajat. Hal ini mengindikasikan bahwa perlu adanya kemauan dan sikap untuk saling melengkapi dari para anggota kelompok. Terutama bagi yang berpendidikan lebih tinggi, karena berkaitan dengan inovasi yang diterimanya. Peternak dengan pendidikan tinggi dapat dijadikan kooperator kegiatan. Fungsi kooperator yaitu sebagai model sekaligus fasilitator bagi anggota kelompok lainnya.

Tabel 1 menggambarkan jumlah tanggungan keluarga anggota kelompok Neglasari lebih banyak (3-6 orang) dibanding anggota kelompok Tanjungan-3 (3-5). Pekerjaan utama anggota kelompok Neglasari maupun Tanjungan-3 yaitu petani dengan rata-rata pendapatan per bulan berkisar Rp 500.000 s.d. Rp 5.000.000. Pendapatan yang diperoleh dari akumulasi seluruh kegiatan yang dilakukan baik hasil dari sawah, sawit, kebun dan sapi. Kisaran pendapatan diduga berkaitan dengan pengalaman usaha sawit, padi dan sapi. Anggota kelompok Neglasari memiliki pengalaman usaha 13 tahun dan luas lahan 59,067 ha, sedangkan anggota kelompok Tanjungan-3 lebih lama yaitu 16,3 tahun dan lahan garapan lebih luas 167,500 ha. Akan tetapi anggota kelompok Neglasari lebih banyak memelihara sapi (1-7 ekor) dengan pengalaman beternak lebih lama 5 tahun, sedangkan 
kepemilikan ternak anggota kelompok Tanjungan-3 hanya 1-6 ekor dengan pengalaman 4,8 tahun.

Pendapatan cenderung berhubungan dengan pemenuhan kebutuhan berdasarkan jumlah tanggungan keluarga. Semakin banyak jumlah keluarga yang ditanggung semakin tinggi biaya yang harus dikeluarkan. Harapannya dengan ragam komoditas (sapi, sawit, padi) yang diusahakan dapat menambah pendapatan baik harian, bulanan maupun musiman. Pendapatan anggota kelompok bersumber dari panen tanaman padi yang diterima setelah 4 bulan sekali dan kelapa sawit 3-4 minggu. Pemeliharan sapi potong belum berorientasi pada skala usaha, karena sifat pemeliharaan sebagai tabungan. Penjualan ternak didasarkan pada kebutuhan. Peluang pendapatan harian dapat diperoleh dari pengolahan dan pemasaran pupuk organik, tetapi anggota kelompok belum melaksanakannya.

\section{Potensi sumber daya alam dan sumber daya manusia}

Cikeusik termasuk salah satu kecamatan di Kabupaten Pandeglang dengan luas 322,76 $\mathrm{km}^{2}$ dan sebagian besar wilayah merupakan dataran rendah dengan ketinggian 5-100 meter di atas permukaan air laut. Kecamatan Cikeusik berbatasan dengan Kecamatan Munjul dan Anjangsana (sebelah Utara), sebelah selatan Samudera Indonesia, sebelah barat Kecamatan Cibaliung dan Cigeulis dan sebelah timur Kabupaten Lebak. Cikeusik merupakan satusatunya kecamatan di Kabupaten Pandeglang yang memiliki perkebunan sawit dengan status milik rakyat. Kondisi ini menarik perhatian pemerintah untuk mengembangkan populasi sapi potong dan berintegrasi dengan kebun kelapa sawit.

Realisasi program berupa bantuan ternak sapi potong pada Oktober 2015 dan diberikan kepada kelompok Tanjungan-3 dan Neglasari, masing-masing kelompok 20 ekor (2 ekor jantan dan 18 ekor betina). Rumpun sapi potong yang didistribusikan yaitu Peranakan Ongole (PO). Pemilihan rumpun disesuaikan dengan karakteristik wilayah dan dengan pertimbangan sapi PO cenderung adaptif di wilayah tersebut. Sapi potong Peranakan Ongole banyak dipelihara dan menempati jumlah terbesar, setelah itu sapi peranakan Simmental, peranakan Limousin, peranakan FH, dan sapi Jawa.

\section{Sosialisasi SISKA}

Sosialisasi sistem integrasi sapi sawit telah dilaksanakan melalui pertemuan pada 10 September 2015. Peserta terdiri atas anggota kelompok Neglasari dan Tanjungan-3. Materi yang dipaparkan lebih menekankan pada inovasi teknologi budidaya dalam pengembangan sapi potong berbasis integrasi sawit-sapi yang bersinergis dengan program Dinas Pertanian dan Peternakan Kabupaten Pandeglang. Dalam kesempatan yang sama juga dibahas tentang pengenalan dan pencegahan peyakit pada ternak.

Hasil identifikasi menunjukkan bahwa, teknologi yang relatif cepat dan mudah diterapkan untuk mendukung integrasi sapi sawit di Kabupaten Pandeglang yaitu teknologi pakan dan pengolahan limbah ternak. Secara partisipatif peternak dilibatkan dalam identifikasi sumber bahan pakan sapi dari limbah sawit dan pengolahan limbah ternak melalui pelatihan pembuatan pupuk organik. Tujuan pelatihan yaitu untuk meningkatkan keterampilan peternak dalam mengolah limbah ternak menjadi pupuk organik. Narasumber pelatihan berasal dari Balit Komoditas maupun BPTP. Pelatihan merupakan metode diseminasi yang dirasa efektif, karena melibatkan partisipasi pesertanya secara aktif. Hal ini sejalan dengan pemikiran Rusnan et. al. (2015) yang menyatakan bahwa pelatihan merupakan pendidikan informal yang dapat meningkatkan pengetahuan peserta. 
Limbah perkebunan sawit di kelompok Neglasari dan Tanjungan-3 yang tersedia hanya pelepah dan daun yang dipangkas. Limbah lainnya berupa tandan buah kosong, limbah cair dan bungkil inti (Ginting 2013) hanya tersedia di pabrik dan lokasinya jauh dari Kecamatan Cikeusik. Dalam pelatihan peserta mendapatkan arahan tentang fungsi pelepah dan daun sawit sebagai sumber hijauan bagi ternak. Peserta diarahkan untuk memanfaatkan alat yang tersedia (chopper) untuk mencacah pelepah dan daun sawit, sebelum diberikan ke sapi. Sumber hijauan bagi sapi di area perkebunan kelapa sawit berasal dari gulma dan pelepah sawit yang dipangkas. Rata-rata 1 ha perkebunan sawit menampung 130 pokok tanaman (jarak 9×9 m). Pelepah segar yang dihasilkan per tahun mencapai 9 ton/ha. Setiap pokok tanaman mampu menghasilkan 22 pelepah/tahun dengan bobot per batang setelah dikupas untuk pakan 2,2 kg (Diwyanto et al. 2003).

Untuk meningkatkan bobot badan sapi, peserta pelatihan mendapatkan pengetahuan tentang perlunya penambahan sumber protein yang tersedia dan mudah didapat seperti dedak/ampas tahu. Alternatif pemecahan masalah disesuaikan dengan ketersediaan sumber daya alam yang ada dan peternak tidak diharuskan untuk menyediakan sumber protein lain dengan resiko biaya yang lebih tinggi. Inovasi teknologi yang disarankan telah disesusaikan dengan sifat inovasi teknologi yang meliputi inovasi dibutuhkan oleh mayoritas petani, memberikan keuntungan konkrit, berkelanjutan, dapat mengatasi faktor pembatas, mendayagunakan sumber daya yang ada (penyedia protein seperti gamal dan lamtoro), terjangkau secara finansial, sederhana dan mudah dicoba, serta mudah diamati (Musyafak \& Tatang 2005).

Praktek pengolahan limbah yang diikuti anggota kelompok Neglasari dan Tanjungan3 yaitu pembuatan pupuk organik berbahan dasar limbah padat dan sisa pakan sapi. Alat yang digunakan berupa cangkul, sekop, dan terpal. Bahan organik yang digunakan praktik yaitu feses dan jerami padi 1 ton dengan dekomposer $1 \mathrm{~kg}$ M-DEC. Dekomposer yang diperkenalkan merupakan produk Balitbangtan. Peserta pelatihan secara langsung mempraktikan pembuatan pupuk organik meliputi pembuatan lapisan bahan organik dan dekomposer. Kemudian bahan organik diratakan setinggi $10 \mathrm{~cm}$ dan ditaburkan dekomposer di atasnya. Lapisan disusun hingga semua bahan digunakan, kemudian ditutup menggunakan terpal. Pengomposan selama 21 hari dan setiap minggu dimonitor perubahan suhu. Agar tidak terlalu panas, maka bahan seminggu sekali dibalik. Ciri pupuk yang sudah jadi seperti tekstur menyerupai tanah, jika diremah tidak lengket, aroma tidak berbau.

\section{Monitoring dan evaluasi pertumbuhan sapi}

Produktivitas sapi PO dipengaruhi oleh faktor genetik dan lingkungan. Peningkatan daging sapi PO secara cepat dapat dilakukan melalui pemberian konsentrat dengan tepat (Wiyatna et al. 2012). Karakteristik sapi potong ditampilkan pada Tabel 2.

Tabel 2. Karakteristik sapi PO di kelompok Neglasari dan Tanjungan-3

\begin{tabular}{|c|c|c|c|c|}
\hline \multirow{3}{*}{ Parameter terukur (rata-rata) } & \multicolumn{4}{|c|}{ Kelompok } \\
\hline & \multicolumn{2}{|c|}{ Neglasari } & \multicolumn{2}{|c|}{ Tanjungan 3} \\
\hline & Jantan & Betina & Jantan & Betina \\
\hline Umur ternak (bulan) & 26,00 & 19,00 & 30,00 & 25,00 \\
\hline Panjang badan $(\mathrm{cm})$ & 102,00 & 100,94 & 96,50 & 98,77 \\
\hline Lingkar dada (cm) & 126,75 & 129,47 & 126,50 & 130,44 \\
\hline Berat badan (kg) & 164,50 & 169,90 & 164,00 & 172 \\
\hline Body condition score (BCS) & 2,75 & 2,38 & 2,50 & 2,33 \\
\hline
\end{tabular}


Berdasarkan Tabel 2, karakteristik sapi PO di dua kelompok ini termasuk di bawah ketentuan Standar Nasional Indonesia (SNI) 7356:2008. Persyaratan kuantitatif sapi PO yang ideal untuk jantan umur $24-<36$ memiliki lingkar dada $138-151 \mathrm{~cm}$ dan panjang badan 130-139 cm. Pejantan umur $\geq 36$ dengan lingkar dada $154-180 \mathrm{~cm}$ dan panjang badan 135-145 $\mathrm{cm}$. Syarat bibit sapi PO betina umur 18-<24 memiliki lingkar dada 135$143 \mathrm{~cm}$ dan panjang badan $115-123 \mathrm{~cm}$. Betina umur $\geq 24$ dengan lingkar dada $134-153 \mathrm{~cm}$ dan panjang badan 125-135 $\mathrm{cm}$. Standar tersebut merupakan acuan baku untuk mendapatkan kualitas bibit yang baik. Panjang badan dan lingkar dada berhubungan dengan bobot badan. Panjang badan dan ligkar dada sapi Peranakan Ongole Poel 3 dan 4 $(3,5-4$ tahun) menunjukkan hubungan yang signifikan $(\mathrm{P}<0,05)$ dengan bobot badan (Mansyur 2010).

Monitoring dan evaluasi (monev) kegiatan dilaksanakan setelah 5 bulan kegiatan berjalan. Tujuan monev yaitu untuk mengetahui penerapan teknologi pakan dan pengolahan limbah sapi. Indikator teknologi diadopsi yaitu pertambahan bobot badan yang optimal melalui pemberian pelepah sawit sebagai hijauan dan penambahan pakan tambahan (sumber protein) untuk sapi serta produksi pupuk organik. Diperoleh hasil bahwa teknologi pakan sapi berbasis limbah sawit belum diterapkan oleh anggota kelompok Neglasari maupun Tanjungan-3. Kendala yang dihadapi yaitu alat pemotong rumput (chopper) yang tersedia tidak dapat dimanfaatkan secara maksimal dan hasil cacahan kurang lembut. Peternak khawatir jika cacahan yang kasar dapat merusak lambung sapi. Solusinya kelompok mengusulkan alat pencacah schredder. Harapannya cacahan yang lembut dapat secara bertahap diberikan kepada sapi. Sapi dapat beradaptasi untuk dapat mengkonsumsi daging pelepah sawit antara 3-4 bulan. Lamanya adaptasi dipengaruhi oleh asal usul ternak, ukuran dan bentuk cacahan daging pelepah, pakan imbuhan sebagai perangsang makan dan keterampilan peternak. Bagian dalam (daging) pelepah sawit yang telah dicacah dapat dijadikan sebagai pengganti pakan hijauan. Kekurangan nutrien dari pelepah sawit dapat dicukupi dengan penambahan solid dan bungkil kelapa. Pertambahan bobot badan harian sapi yang mengkonsumsi pakan dasar pelepah sawit dengan penambahan fermentasi (solid dan bungkil inti sawit) dapat mencapai 0,6 kg (Mathius et al. 2005). Monev terhadap produktivitas sapi menunjukkan bahwa penambahan populasi dan peningkatan bobot badan sapi belum menjadi tujuan utama kelompok. Diduga salah satu faktor penyebabnya yaitu rendahnya pemahaman peternak terhadap pemenuhan kebutuhan dan gizi ternak serta sifat kepemilikan ternak sebagai tabungan.

Sistem pemeliharaan di kedua kelompok yang cenderung sama (semi intensif). Pagi hari diumbar di kebun sawit dengan pakan seadanya dan sore hari dikandangkan dengan pemberian pakan rumput/jerami padi kering sesuai ketersediaan. Jumlah sapi pada Oktober 2015 sebanyak 40 ekor menjadi 38 ekor pada Maret 2016. Penurunan jumlah sapi potong di kelompok Neglasari karena ada ternak yang mati. Penyebab kematian ternak yaitu malnutrisi (1 ekor) dan kecelakaan/terperosok (1 ekor). Dampak yang disebabkan oleh malnutrisi berupa penurunan bobot badan hingga kematian. Hasil pengamatan, rata-rata bobot awal (Oktober 2015) di dua kelompok yaitu 170,3 kg/ekor. Kurun waktu 5 bulan mengalami penurunan bobot badan menjadi 132,5 kg/ekor (Maret 2016). Hal ini menggambarkan selain malnutrisi ternak sapi juga mengalami cacingan.

Teknologi pengolahan limbah mulai diadopsi oleh peternak. Anggota kelompok yang membuat pupuk organik setelah pelatihan merupakan peternak yang memelihara sapi secara koloni di kandang kelompok. Hasil monev diketahui bahwa rata-rata peternak yang membuat pupuk organik sekitar 3-4 orang, baik di kelompok Neglasari maupun Tanjungan-3. Rata-rata pupuk yang dihasilkan 3 ton dengan menggunakan dekomposer yang telah dibagikan setelah pelatihan. 


\section{KESIMPULAN}

Kajian ini memperlihatkan bahwa karakteristik individu, karakteristik usaha sapi sawit dan potensi wilayah mampu menjadi kekuatan untuk mengembangkan sistem integrasi sapi sawit di Kabupaten Pandeglang. Sosialisasi kegiatan merupakan langkah awal untuk memberikan pengetahuan kepada anggota kelompok tentang pentingnya sistem integrasi sapi sawit. Adanya penurunan populasi dan bobot badan sapi serta belum diterapkannya teknologi pakan dan pembuatan pupuk organik, maka beberapa hal perlu diperhatikan untuk mengembangkan sistem integrasi sapi sawit di Kabupaten Pandeglang meliputi: pengotimalan pemanfaatan sumber daya alam berbasis sapi sawit, peningkatan pemahaman peternak tentang pentingnya integrasi sapi sawit dan adopsi teknologi, dukungan pemerintah disertai pendampingan yang intensif dan berkelanjutan.

\section{DAFTAR PUSTAKA}

Afriani H, Nahri Idris, Fatati. 2014. Minat dan motivasi peternak untuk mengembangkan ternak sapi pada kawasan perkebunan kelapa sawit di Provinsi Jambi. J Ilmiah Ilmu-Ilmu Peternak. XVII:77-83.

Ahmad J. 2014. Faktor-Faktor Yang Mempengaruhi Curahan Waktu Kerja Dalam Usaha Trenak Sapi Potong di Desa Barabatu Kecamatan Labakkang Kabupaten Pangkep. [Skripsi]. [Makassar (Indonesia)]: Universitas Hasanuddin.

BPS. 2014. Statistik Indonesia 2014. Jakarta (Indonesia): Badan Pusat Statistik.

Diwiyanto K, D.M Sitompul, Ishak Manti, I-Wayan Mathius, Soentoro. 2003. Pengkajian Pengembangan Usaha Sistem Integrasi Kelapa Sawit-Sapi. Dalam: Setiadi B, Mathius IW, Inounu I, Djajanegara A, Adjid RMA, Risdiono B, Lubis D, Priyanti A, Priyanto D, penyunting. Prosiding Lokakarya Nasional Sistem Integrasi Kelapa Sawit-Sapi 2003. Bengkulu, 9-10 September 2003. Bogor (Indonesia): Pusat Penelitian dan Pengembangan Peternakan bekerjasama dengan Pemerintah Provinsi Bengkulu dan PT Agricinal. hlm. 11-22.

Ginting SP. 2013. Nutrisi dan pakan kambiing dalam sistem integrasi dengan tanaman. Matius IW, penyunting. Jakarta (Indonesia): IAARD Press. hlm. 68-74.

Manurung BP. 2005. Sistem Integrasi Sawit Model Acrinal (SISKA). Dalam: Diwyanto K, Inounu I, Djajanegara A, Mathius IW, Haryanto B, Priyanti A, Handiwirawan E, penyunting. Prosiding Lokakarya Pengembangan Sistem Integrasi Kelapa Sawit-Sapi. Banjarbaru, 22-23 Agustus 2005. Banjarbaru (Indonesia): Puslitbangnak. hlm.20-23.

Mansyur MSA. 2010. Hubungan Antara Ukuran Eksterior Tubuh Terhadap Bobot Badan Sapi Peranakan Ongole (PO) Jantan [Skripsi]. [Surakarta (Indonesia)]: Universitas Sebelas Maret.

Mathius IW, Sinurat AP, Manurung BP, Sitompul DM, Azmi. 2005. Pemanfaatan produk fermentasi lumpur bungkil Sebagai Bahan Pakan Sapi Potong. Dalam: Mathius IW, Bahri S, Tarmudji, Prasetyo LH, Triwulanningsih E, Tiesnamurti B, Sendow I, Suhardono, penyunting. Inovasi teknologi peternakan untuk meningkatkan kesejahteraan masyarakat dalam mewujudkan kemandirian dan ketahanan pangan nasional. Prosiding Seminar Nasional Teknologi Peternakan dan Veteriner. Bogor, 12-13 September 2005. Bogor (Indonesia): Puslitbangnak. hlm. 153-161.

Musyafak, Tatang. 2005. Strategi percepatan adopsi dan difusi inovasi pertanian mendukung prima tani. J Anal Kebijak Pertan. 3:20-37.

Prabowo A, Basri E, Tambuan RD, Soerachman. 2008. Teknologi budidaya sapi potong. Bogor (Indonesia): Balai Besar Pengkajian dan Pengembangan Teknologi Pertanian. 
Rusnan H, Kaunang CL, Tulung YLR. 2015. Analisis potensi dan strategi pengembangan sapi potong dengan pola integrasi kelapa-sapi di Kabupaten Halmahera Selatan Provinsi Maluku Utara. J Zootek. 35:187-200.

Satori D, Komariah A. 2009. Metodologi penelitian kualitatif. Bandung (Indonesia): Alfabeta.

Setiadi B, Diwyanto K, Puastuti W, Mahendri IGAP, Tiesnamurti B. 2011. Peta potensi dan sebaran areal perkebunan kelapa sawit di Indonesia: Sistem Integrasi Sapi-Kelapa Sawit (SISKA). Bogor (Indonesia): Pusat Penelitian dan Pengembangan Peternakan.

Wijono BD, Affandhy L, Ainur Rasyd. 2003. Integrasi Ternak Dengan Perkebunan Kelapa Sawit. Dalam: Dalam: Setiadi B, Mathius IW, Inounu I, Djajanegara A, Adjid RMA, Risdiono B, Lubis D, Priyanti A, Priyanto D, penyunting. Prosiding Lokakarya Nasional Sistem Integrasi Kelapa Sawit-Sapi 2003. Bengkulu, 9-10 September 2003. Bogor (Indonesia): Pusat Penelitian dan Pengembangan Peternakan bekerjasama dengan Pemerintah Provinsi Bengkulu dan PT Agricinal. hlm. 147-155.

Wiyatna MF, Gunardi E, Mudikdjo K. 2012. Produktivitas sapi peranakan ongole pada peternakan rakyat di Kabupaten Sumedang (Productivity of Peranakan Ongole Cattle on Traditional farm sytem in Sumedang Region). J Ilmu Ternak. 12:22-25.

\section{DISKUSI}

\section{Pertanyaan}

1. Mohon penjelasan pelepah sawit yang diberikan ke sapi bisa dilakukan, demikian juga pengolahan kotoran sapi, sebagai perbandingan.

2. Apa sudah ada penelitian tentang komposisi bahan?

3. Bagaimana komposisi ransum sebelum dan sesudah diberi limbah sawit. Apa perlu sampai 5 bulan? Apa ada tindakan atau hal lain yang diperoleh peternak pemilik sapi karena secara hitungan peternak rugi?

4. Harusnya pembahasan lebih mendetail, dilihat kandungan nutrien batang daun dan penggunaan pupuk organik karena tiap daerah kandungan nutriennya berbeda, areal berapa luas sehingga diketahui dampaknya?

\section{Jawaban}

1. Kegiatan sifatnya masih introduksi jadi sebagai pengetahuan awal. Karena kepemilikan hanya sekitar 2-3 ekor saja, jadi bantuan hanya bersifat stimulus. Kotoran sapi dapat dimanfaatkan untuk sawit, mereka sudah membuat pupuk kandang yang belum diolah. Teknologi pengomposan sudah kami introduksikan. Di Cikesik hampir setengah luas kecamatan harus diukur berapa kotoran sapi yang dihasilkan per hari. Untuk yang sudah produksi pupuk organik dihasilkan 3 ton/3 bulan, memang kelemahannya analisis belum dilakukan lebih jauh.

2. Waktu itu (September 2015-Maret 2016) tidak full di sana. Sebelumnya sudah ada survey, bukan dihitung setelah bantuan datang. Setelah ada bantuan, evaluasi hanya 2 minggu, bulan maret baru evaluasi secara keseluruhan. Kegiatan ini tidak dilakukan dengan intensif, dari segi waktu untuk detail masih kurang. Dari segi gizi daun, daging dan pelepah, solid dan limbah tidak ditampilkan. Di Banten hanya satu pengolah kelapa sawit itupun di kabupaten yang berbeda dengan daerah penghasil sawitnya. Hasil diskusi kami limbah pabrik tidak direkomendasikan untuk pakan. Yang ada untuk 
mencacah saja bukan untuk bahan pakan, sedangkan untuk penelitian palatabilitas daun saja memerlukan waktu lama.

3. Untuk ransum, kami tidak menyusun ransum, tapi hanya memotivasi pentingnya integrasi. Target tersosialisasi dan teradopsi menjadi tidak dapat terlaksana karena pola pemeliharaan sapi siang di kebun sawit dan malam dipulangkan. Untuk hitungan analisis untung dan rugi tahun 2013-2017 kami masih sulit menghitung skala ekonomi, jadi belum berani menentukan untung atau ruginya.

4. Jawaban yang sama seperti sebelumnya, kegiatan ini tidak dilakukan dengan intensif, dari segi waktu untuk detail masih kurang. Dari segi gizi dari daun, daging dan pelepah, solid dan limbah tidak ditampilkan. 